\title{
Isolation and Partial Characterization of a Novel Cytorhabdovirus from Citrus Trees Showing Foliar Symptoms in Iran
}

Mohammad Sadegh Sadeghi, Alireza Afsharifar, and Keramatollah Izadpanah, Plant Virology Research Center, College of Agriculture, Shiraz University, Shiraz, Iran; Giuliana Loconsole and Angelo De Stradis, Istituto per la Protezione Sostenibile delle Piante, UOS Bari, Consiglio Nazionale delle Ricerche, 70126 Bari, Italy; Giovanni P. Martelli, Dipartimento di Scienze del Suolo, della Pianta e degli Alimenti, Università degli Studi di Bari Aldo Moro, 70126 Bari, Italy; and Maria Saponari, Istituto per la Protezione Sostenibile delle Piante, UOS Bari, Consiglio Nazionale delle Ricerche

\begin{abstract}
Sadeghi, M. S., Afsharifar, A., Izadpanah, K., Loconsole, G., De Stradis, A., Martelli, G. P., and Saponari, M. 2016. Isolation and partial characterization of a novel cytorhabdovirus from citrus trees showing foliar symptoms in Iran. Plant Dis. 100:66-71.

Citrus ringspot is a graft-transmissible disease, and at least two taxonomically distinct viral species are associated with this syndrome: Citrus psorosis virus (CPsV) and Indian citrus ringspot virus (ICRSV). Neither of these two viruses was detected, however, by serological or molecular assays in symptomatic tissues from citrus trees in southern Iran, where the ringspot syndrome is widespread. By contrast, electron microscopy and molecular assays revealed the presence of a rhabdovirus-like virus, which

was graft transmitted to several citrus species and mechanically to herbaceous hosts. Virus particles were bacilliform and resembled rhabdovirus nucleocapsids deprived of the lipoprotein envelope. Partial sequences of the viral nucleoprotein and RNA polymerase genes showed a distant genetic relatedness with cytorhabdoviruses. This virus appears to be a novel species, for which the name Iranian citrus ringspot-associated virus (IrCRSaV) is suggested.
\end{abstract}

Chlorotic to yellow ringspots of citrus leaves were reported on citrus in different countries (Bové 1995; Roistacher 1993; Timmer et al. 2000). At least two taxonomically distinct RNA viruses have been associated with this symptomatology: Citrus psorosis virus (CPsV), the type member of the genus Ophiovirus, whose particles are naked filamentous nucleocapsids (Milne et al. 2000); and Indian citrus ringspot virus (ICRSV), the type member of the genus Mandarivirus, a virus with flexuous filamentous particles (Rustici et al. 2000, 2002).

A ringspot syndrome of sweet orange and several other citrus species, characterized by small chlorotic and necrotic rings, mostly along the veins of mature leaves, was observed in Iran in the late 1970s (Izadpanah and Rahimian 1978) and was graft transmitted to a number of citrus species (Amiri et al. 1992). This disease is widespread in the southern part of the country, where natural infections occur on sweet orange (Citrus sinensis), sweet lime (C. limetta), lemon (C. limon), citron (C. medica), and bakraee ( $C$. reticulata hybrid). Serological and molecular tests for the presence of CPsV in symptomatic trees were consistently negative, although the possible causal agent is thought to be an RNA virus (Yassaie and Izadpanah 2000).

Here, a study encompassing biological assays, electron microscopy, and partial sequencing of the viral genome was carried out on sweet orange trees exhibiting ringspot syndrome. This study revealed the presence of a novel rhabdovirus-like virus associated with infected trees. A provisional name of Iranian citrus ringspotassociated virus (IrCRSaV) was proposed for this novel virus species.

\section{Materials and Methods}

Source of virus isolates. In 2012, 10 sweet orange trees with typical symptoms were selected in 25- to 30-year-old groves in the Khafr region (100 km south east of Shiraz, Iran). Buds from each

Corresponding author: M. Saponari; E-mail: maria.saponari@ipsp.cnr.it

Accepted for publication 20 June 2015.

http://dx.doi.org/10.1094/PDIS-02-15-0136-RE

(C) 2016 The American Phytopathological Society tree were grafted on sour orange seedlings and maintained in a greenhouse $\left(24\right.$ to $28^{\circ} \mathrm{C}$ ) until symptoms appeared on the new leaves. Newly developed, symptomatic tissues were used in the experiments described hereafter. One of the 10 sources, designated CR-Ir, was selected for electron microscopy and molecular investigations.

Biological assays. Tissues from symptomatic leaves were macerated in the presence of $0.01 \mathrm{M}$ potassium phosphate buffer, $\mathrm{pH} 7$, and the extract was used for mechanical inoculation of 21 different herbaceous hosts in the families Amaranthaceae, Solanaceae, Chenopodiaceae, Cucurbitaceae, Fabaceae, Malvaceae, and Geraniaceae (Table 1). Briefly, the plant sap was rubbed onto the surface of leaves previously dusted with carborundum. Leaves were then rinsed with water.

In addition, buds from symptomatic shoots were used for graft inoculating a triplet set of 8- to 12-month-old seedlings of sweet orange (C. sinensis), Mexican lime (C. aurantifolia), sour orange (C. aurantium), grapefruit (C. paradisi), and trifoliate orange (Poncirus trifoliata). Inoculated plants and mock-inoculated controls of the same species were maintained in a greenhouse at 24 to $28^{\circ} \mathrm{C}$, and observed for symptom appearance.

Electron microscopy. A Philips Morgagni 282D electron microscope was used for the observation of (i) leaf dips from symptomatic tissues of the source CR-Ir and infected French bean mounted in 2\% uranyl acetate (Milne 1993) and (ii) thin-sectioned leaf tissue fragments from the CR-Ir source, infected grapefruit, and healthy controls, processed as described by Martelli and Russo (1984).

Assays for known citrus viruses. Total nucleic acids were extracted from symptomatic leaves of each source, using a cetyltrimethylammonium bromide-based protocol (Saponari et al. 2013) and subjected to conventional or real-time polymerase chain reaction (PCR) or reverse-transcription (RT)-PCR assays to screen trees for the presence of the main citrus-infecting viruses that occurred in this region: CPsV, ICRSV, Citrus tristeza virus (CTV), Citrus leaf blotch virus, Citrus variegation virus, Citrus chlorotic dwarf-associated virus (CCDaV), and Citrus yellow vein clearing virus (CYVCV). Amplification conditions were as previously described (Loconsole et al. 2010, 2012a,b; Roy et al. 2005; Ruiz-Ruiz et al. 2009; Sharma et al. 2009). Genus-specific primers were also used in RT-PCR assays for the identification of putative potyviruses (Ha et al. 2008), 
ophioviruses (Vaira et al. 2003), betaflexiviruses (Dovas and Katis 2003), and begomoviruses (Deng et al. 1994).

Random cDNA synthesis, cloning, and sequencing. To gain insight into the molecular properties of the putative viral agent, a random-primed cDNA library was constructed. Total RNA $(1 \mu \mathrm{g})$ was recovered from a partially purified preparation (Jackson and Christie 1977) from symptomatic leaves of French bean mechanically inoculated with CR-Ir. Briefly, first-strand cDNA was synthesized with random decamer nucleotides as primers (RETROscript Kit; Life Technologies). cDNA templates were then synthesized, converted into double-stranded DNA, bluntended with T4 DNA polymerase, and ligated into the plasmid pUC19. Thirty recombinant clones containing PCR products of $500 \mathrm{bp}$ in size or larger were selected and sequenced in both directions.

Sequence analysis. Nucleotide sequences were compared with the nonredundant GenBank database using the BLASTX and BLASTN algorithms, and searched for conserved protein domains using the National Center for Biotechnology Information (NCBI) Conserved Domain Database (www.ncbi.nlm.nih.gov/cdd). Sequences that showed significant genetic homology to plant viral genomes were selected for further analyses. Phylogenetic analysis was done by the distance-based Clustal W method using the software MEGA 5 (Tamura et al. 2011).

Specific detection of IrCRSaV by conventional and quantitative RT-PCR. Two sets of specific primers (IrF-5'-TCAT TAGACTGGGATAGAGC-3'/IrR-5'-CCAACTTCCCTGGCTTCT AG-3' and IrPol-F-5'-CCCAGAACACATCTAGAGAGCAGGA3'/IrPol-r-5'-CATATCGGGGGTTTGAAGGA) yielding PCR products of 260 and $676 \mathrm{bp}$ were designed based on the nucleoprotein (clone Ir90, GenBank accession number KP255975) and RNA polymerase (clone Ir119, GenBank accession number KP255976) gene sequences, respectively. Total RNA was isolated from the leaves using a commercial RNA isolation kit (DENAzist Asia). For conventional PCR, RT was carried out in a total reaction volume of $25 \mu \mathrm{l}$ at $42^{\circ} \mathrm{C}$ for $60 \mathrm{~min}$ using $5 \mu \mathrm{l}$ of total RNA (at a

Table 1. Reaction of herbaceous hosts mechanically inoculated with Iranian citrus ringspot-associated virus

\begin{tabular}{|c|c|}
\hline Test plant & Symptoms \\
\hline \multicolumn{2}{|l|}{ Amaranthaceae } \\
\hline Gomphrena globosa & - \\
\hline \multicolumn{2}{|l|}{ Chenopodiacea } \\
\hline Beta vulgaris & - \\
\hline Chenopodium amaranticolar & LL \\
\hline C. quinoa & LL \\
\hline \multicolumn{2}{|l|}{ Cucurbitaceae } \\
\hline Citrullus lanatus & - \\
\hline Cucumis melo & - \\
\hline C. sativus & - \\
\hline Cucurbita Реро & - \\
\hline \multicolumn{2}{|l|}{ Leguminosae } \\
\hline Phaseolus vulgaris & M \\
\hline Vicia faba & - \\
\hline Vigna radiata & - \\
\hline V. unguiculata & - \\
\hline \multicolumn{2}{|l|}{ Geraniaceae } \\
\hline Pelargonium zonale & - \\
\hline \multicolumn{2}{|l|}{ Mavalaceae } \\
\hline Gossypium herbaceum & - \\
\hline \multicolumn{2}{|l|}{ Solanaceae } \\
\hline Capsicum аппиит & - \\
\hline Datura metel & - \\
\hline D. stramonium & - \\
\hline Solanum lycopersicum & - \\
\hline Nicotiana glutinosa & - \\
\hline N. tabacum 'Turkish' & - \\
\hline Physalis sp. & - \\
\hline
\end{tabular}

${ }^{\text {a }} \mathrm{LL}=$ local lesion, $\mathrm{M}=$ mosaic, and $-=$ no symptoms concentration of $50 \mathrm{ng} / \mu \mathrm{l}$ ), adding $10 \mathrm{mM}$ each dNTP, $200 \mathrm{U}$ of M-MuLV (Fermentas), and $0.5 \mu \mathrm{M}$ reverse primer. PCR was then carried out in a $25-\mu 1$ reaction volume following standard amplification conditions.

A quantitative one-step SYBR Green I-based RT-PCR system was also developed using the aforementioned primers IrF and IrR. Amplification was carried out in a $12.5-\mu 1$ reaction mixture containing $1 \times$ SYBR Select Master Mix (Applied Biosystems), $320 \mathrm{nM}$ each primer, and $0.15 \mu \mathrm{l}$ of M-MuLV (Fermentas). The thermal profile for one-step SYBR Green-based RT-PCR consisted of a 15-min RT step at $42^{\circ} \mathrm{C}$ and $10 \mathrm{~min}$ at $95^{\circ} \mathrm{C}$, followed by 40 cycles at $95^{\circ} \mathrm{C}$ for $10 \mathrm{~s}, 55^{\circ} \mathrm{C}$ for $30 \mathrm{~s}$, and $72^{\circ} \mathrm{C}$ for $30 \mathrm{~s}$. Following amplification, a melting curve analysis was done to verify the correct product by its specific melting temperature (Tm). Melting curves of PCR amplicons were obtained with temperatures ranging from 65 to $90^{\circ} \mathrm{C}$. Data were recorded for every $0.2^{\circ} \mathrm{C}$ of temperature at 10 -s intervals. Ten-fold serial dilutions were prepared using the total nucleic acids extracted from the selected source CR-Ir, subjected to quantitative (q)RT-PCR, and the resultant quantitation cycles were used to determine the efficiency of the assay.

All PCR reactions included positive, negative, and nontemplate controls. The specificity of the assay was verified by testing samples collected from the citrus virus collection at the University of Bari, which included CTV, CPsV, CCDaV, and CYVCV. Conventional and real-time PCR assays were validated on a panel of 40 field samples, consisting of mature leaves collected from 30 symptomatic sweet orange trees and 10 symptomless trees. Assays were also extended to assess the presence of the putative novel virus in young, symptomless leaves collected from symptomatic sour orange (C. aurantium) indicator plants.

\section{Results}

Field symptoms. Typical ringspot symptoms observed in most local sweet orange cultivars in Khafr consisted of small rings, etched lines, and chlorotic spots on both sides of the mature leaves (Fig. 1). The rings often followed the lateral veins and turned necrotic as the leaves aged. No specific symptoms were found on fruit. Not all branches of a tree were symptomatic but affected trees were less vigorous than the healthy ones.

Host range and graft transmission. Among herbaceous hosts, Phaseolus vulgaris reacted with systemic vein clearing and extensive leaf mottling (Fig. 2A) 14 days postinoculation (dpi), whereas Chenopodium quinoa (Fig. 2B) and C. amaranticolor showed chlorotic local lesions 10 dpi but no systemic symptoms.

Within 3 months from graft inoculation, chlorotic flecking, rings, and line patterns were observed on the leaves of trifoliate orange (Fig. 2C), Mexican lime, grapefruit, and sour orange (Fig. 2D). These lesions later transformed into necrotic spots (Fig. 2E). Yellow mottling

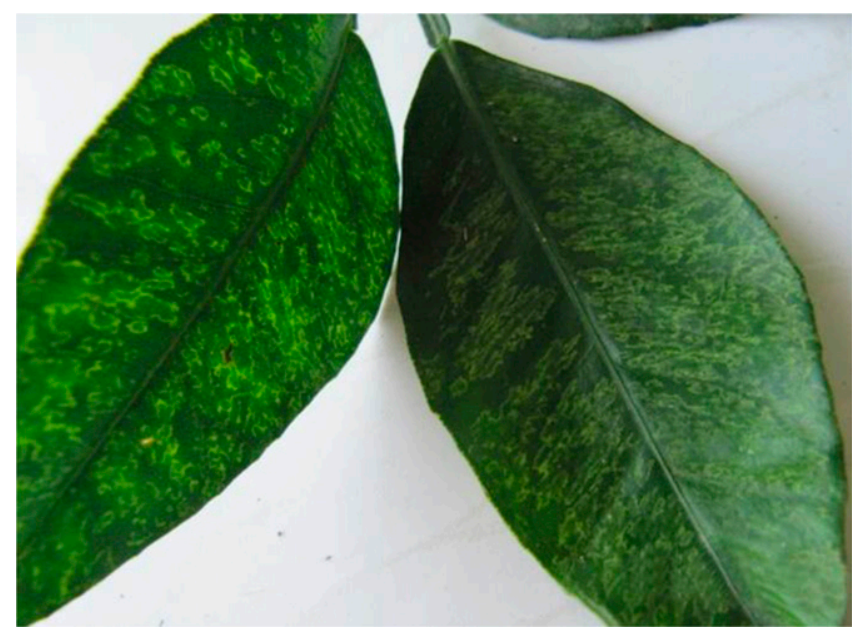

Fig. 1. Ringspot symptoms on mature leaves of sweet orange in the orchards of Fars Province, Iran. 
and ringspots were also seen on the stems of young shoots of trifoliate orange (Fig. 2F). Mock-inoculated seedlings remained symptomless. All symptomatic hosts were positive for the presence of IrCRSaV when tested by RT-PCR using the specific primers $\mathrm{IrF} / \mathrm{IrR}$.

Electron microscopy. Leaf dips from CR-Ir source and French bean showed the presence of bacilliform particles about 450 by $30 \mathrm{~nm}$ in size, showing prominent transverse striations and resembling very much nonenveloped rhabdoviral nucleocapsids (Fig. 3A). The particle size represents the mean of the measurements performed on 48 and 55 viral particles from citrus and bean, respectively. Measurements were performed using the software IMAGE 1.38, and statistic evaluations using KALEIDAGRAPH 3.2. In thin-sectioned samples, the most conspicuous cytopathological feature was the presence in the cytoplasm of mesophyll cells of rounded electron-dense inclusion bodies with a finely fibrillar-granular texture, close to or apposed to the cell wall (Fig. 3B). These bodies were surrounded by dark dots and elongated structures (Fig. 3B, inset), which were interpreted as transversally and tangentially sectioned virus particles, respectively. On this account, these inclusions were tentatively identified as viroplasm matrices. No such inclusions were seen in the healthy controls.

Sequencing and phylogenetic analysis. Of the 30 nucleotide sequences assembled from the selected clones, none shared significant similarity with the viral sequences from the NCBI database following BLAST analysis. However, the predicted amino acid sequences of two clones, denoted Ir90 (500 bp, GenBank accession number KP255975) and Ir119 (2,825 bp, GenBank accession number KP255976), appeared of possible viral origin because they shared an amino acid identity of 27 to $39 \%$ with nucleoproteins ( $N$ protein) and RNA polymerase (L protein) of the following cytorhabdoviruses: Northern cereal mosaic virus (NCMV), Lettuce yellow mottle virus (LYMV), Lettuce necrotic yellows virus, and Barley yellow striate mosaic virus (BYSMV) (Table 2).

Furthermore, multiple alignment of the L protein genes identified three conserved domains in the clone Ir119: (i) the catalytic domain III (cl15638) of the L proteins of Mononegavirales and other nonsegmented negative-strand RNA viruses, which starts at nucleotide position 2 and terminates at nucleotide position 2,290; this domain comprised the four distinct conserved motifs A, B, C, and D (Poch et al. 1990) (Fig. 4A), thought to play an essential role for RNA polymerase activity (Schnell and Conzelmann 1995); (ii) the mRNA-capping domain V (c116796) of L RNA polymerase belonging to nonsegmented negative-sense RNA viruses and Mononegavirales, which included the motif $\mathrm{G}(\mathrm{SY}) \mathrm{T}(\mathrm{k})(\mathrm{n})$ HR from nucleotide position 2,578 to nucleotide position 2,810; and (iii) the mRNA capping C-terminal region (TIGR04198) shared by paramyxovirus-like RNA-dependent RNA polymerases (L protein).

In a phylogenetic tree constructed with the deduced amino acid sequences of the partial $\mathrm{L}$ protein, IrCRSaV clustered with the cytorhabdoviruses BYSMV and NCMV on a branch starting from the same node but on a separate clade (Fig. 4B). Likewise, a phylogenetic analysis based on the partial $\mathrm{N}$ protein genes positioned IrCRSaV among cytorhabdoviruses in the same clade as NCMV (Fig. 4C).

IrCRSaV detection. Total nucleic acids subjected to RT-PCR assays amplified DNA bands of the expected sizes, $260 \mathrm{bp}$ using the primers $\mathrm{IrF} / \mathrm{IrR}$ (Fig. 5A) and $646 \mathrm{bp}$ using the primers Ir-Pol-f/IrPol-r (not shown), from all symptomatic indicator plants and the panel of 30 selected field trees showing typical disease symptoms. In addition, positive results were obtained for the five samples consisting of symptomless young leaves harvested from symptomatic graft-inoculated sour orange plants.

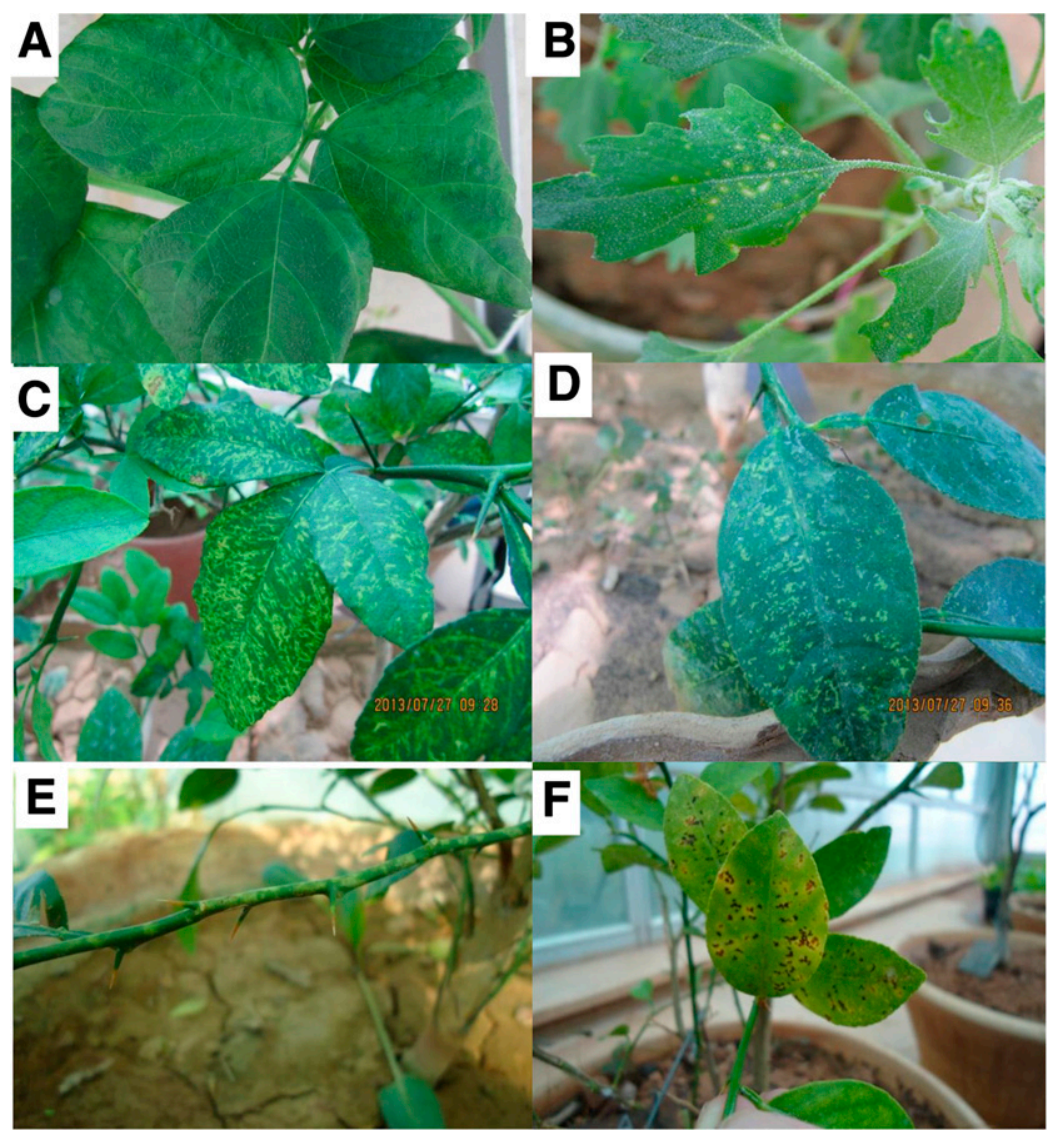

Fig. 2. Symptoms in host plants mechanically inoculated with Iranian citrus ringspot-associated virus. A, Mottling and vein clearing in Phaseolus vulgaris; B, chlorotic local lesions in Chenopodium quinoa; $\mathbf{C}$ and $\mathbf{D}$, chlorotic flecks, rings, and line patterns on the leaves of Poncirus trifoliata and Citrus aurantium; $\mathbf{E}$, mottling on stems of $P$. trifoliata; $\mathbf{F}$, necrotic spots appearing in the late stage of the infections. 
The same samples tested negative when assayed for the presence of other known citrus viruses, further confirming that neither $\mathrm{CPsV}$ nor ICRSV are involved in the Iranian citrus ringspot disease.

In addition, IrCRSaV was readily detected using the one-step qRT-PCR protocol developed in this study, with resultant quantitation cycles of 18 to 23 from tissue prepared from symptomatic indicator plants and field samples (Fig. 5B). No signals were detected in the healthy and nontemplate controls, or in the samples harvested from symptomless trees. Following the Tm analysis, a single and specific melting peak, with a Tm of 80 to $50^{\circ} \mathrm{C}$, was obtained from all positive samples (Fig. 5C) The efficiency of the qRT-PCR assays was about $90 \%$, close to the optimum value, as determined on the
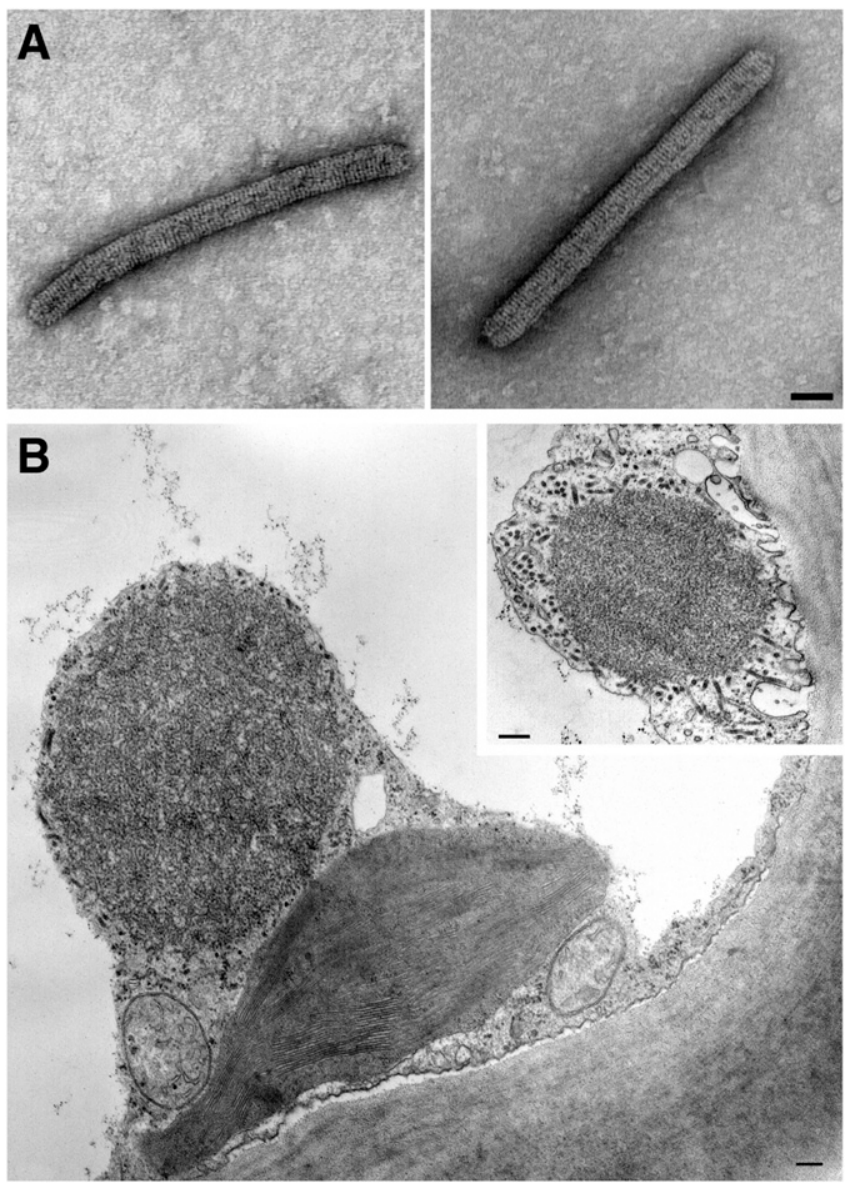

Fig. 3. A, Negatively stained virus particles from symptomatic leaves of sweet orange (left) and French bean (right). Bars $=50 \mathrm{~nm}$. B, Electron-dense inclusion body with a granular-fibrillar texture in a mesophyll leaf cell of sweet orange. Bar $=200 \mathrm{~nm}$. Inset: Inclusion body in a mesophyll cell in a grapefruit leaf. Strongly electron-opaque dots and elongated structures surrounding the body are interpreted as cross- and tangentially sectioned virus particles. Bar $=100 \mathrm{~nm}$. basis of the regression coefficient $\left(r^{2}=0.993\right)$ of the standard curve generated by 10 -fold serial dilutions of the total nucleic acid preparation (data not shown)

\section{Discussion}

Sequences of a novel viral pathogen (IrCRSaV) were consistently found in Iranian citrus trees affected by a ringspot syndrome, in accordance with previous indications (Yassaie and Izadpanah 2000) that an unidentified graft-transmissible agent unrelated to CPsV and ICRSV is associated with these symptoms.

IrCRSaV has a genome sharing very little sequence homology with members of the family Rhabdoviridae, and has nonenveloped bacilliform particles resembling those of members of this family. Two nucleorhabdoviruses, Citrus necrotic spot virus and nuclear Citrus leprosis virus, with nonenveloped bacilliform particles ( 40 to 50 by 100 to $110 \mathrm{~nm}$ ) and a bipartite genome have been found in citrus trees (Cruz-Jaramillo et al. 2014; Roy et al. $2015)$. Both viruses share a high sequence identity (>90\%) with Orchid fleck virus, and their inclusion in Dichorhavirus, a new genus in the family Rhabdoviridae (Dietzgen et al. 2014), has been proposed.

Phylogenetic analysis using the partial amino acid sequences of the $\mathrm{N}$ and $\mathrm{L}$ proteins showed that IrCRSaV clusters with cytorhabdoviruses and is genetically distant from the two putative dichorhaviruses reported previously in citrus (Cruz-Jaramillo et al. 2014; Roy et al. 2015). However, distinct differences between IrCRSaV and cytorabdoviruses include the size ( 450 by $30 \mathrm{~nm}$ versus 130 to 350 by 45 to $100 \mathrm{~nm}$ ) and appearance (nonenveloped versus enveloped) of the virions and the presence of viroplasm matrices. Wide differences in particle appearance, genome structure, and cytopathological features exist also with members of other plant virus genera such as Cilevirus (Locali-Fabris et al. 2012) and Dichorhavirus (Dietzgen et al. 2014), both of which have nonenveloped smaller bacilliform particles (120 to 130 by 50 to $55 \mathrm{~nm}$ for cileviruses and 100 to 150 by 40 to $45 \mathrm{~nm}$ for dichorhaviruses) and a bipartite genome.

Taken together, these results provide evidence that IrCRSaV is an undescribed virus with a distant phylogenetic relationship with members of the genus Cytorhabdovirus. Further work involving metagenomic approaches (i.e., next-generation sequencing technology), purification, and insect vector transmission tests are planned for determining the taxonomic position of IrCRSaV, elucidating its biological, serological, and molecular features and its role in the etiology of the ringspot syndrome with which it is associated.

Because little information was available regarding the causative agent of this ringspot disease, and its spread and incidence in Iran, no preventive or control measures have been undertaken. Therefore, the diagnostic protocols developed herein represent valuable tools for the implementation of control strategies involving (i) surveys to estimate disease incidence and demarcation of the infected areas, (ii) virus detection in candidate insect vectors, (iii) studies on disease epidemiology, (iv) evaluation of tolerance

Table 2. BLAST X search for amino acid sequence similarity (\%) between the two viral sequences (clones Ir90 and Ir119) from ringspot-affected citrus trees and the most closely related plant rhabdoviruses

\begin{tabular}{|c|c|c|c|}
\hline \multirow[b]{2}{*}{ Genus } & \multirow[b]{2}{*}{ Virus name (GenBank accession number) } & \multicolumn{2}{|c|}{ Sequence identity $(\%)^{\mathrm{a}}$} \\
\hline & & Ir90 (KP255975) N protein & Ir119 (KP255976) L protein \\
\hline \multirow[t]{4}{*}{ Cytorhabdovirus } & Northern cereal mosaic virus (ADE61677) & $29(2 \mathrm{e}-09)$ & $39(0.0)$ \\
\hline & Lettuce yellow mottle virus (YP_002308376) & $29(2 \mathrm{e}-05)$ & $37(3 e-172)$ \\
\hline & Lettuce necrotic yellows virus (YP_425092) & $27(8 \mathrm{e}-04)$ & $37(1 \mathrm{e}-177)$ \\
\hline & Barley yellow striate mosaic virus (ACT21686) & None & $39(0.0)$ \\
\hline \multirow[t]{2}{*}{ Nucleorhabdovirus } & Taro vein chlorosis virus (YP_224083) & $24(0.051)$ & $32(2 \mathrm{e}-126)$ \\
\hline & Potato yellow dwarf virus (YP_004927971) & None & $31(2 \mathrm{e}-125)$ \\
\hline \multirow[t]{2}{*}{ Dichoravirus } & Citrus necrotic spot virus (AGQ21972 - AGQ21977) & None & $32(3 e-128)$ \\
\hline & Citrus leprosis virus nuclear type (AIH07332 - AGN91973) & None & $32(2 \mathrm{e}-129)$ \\
\hline
\end{tabular}

a Predicted gene products; percent identity, with E-value in parenthesis. None = no similarity found. 

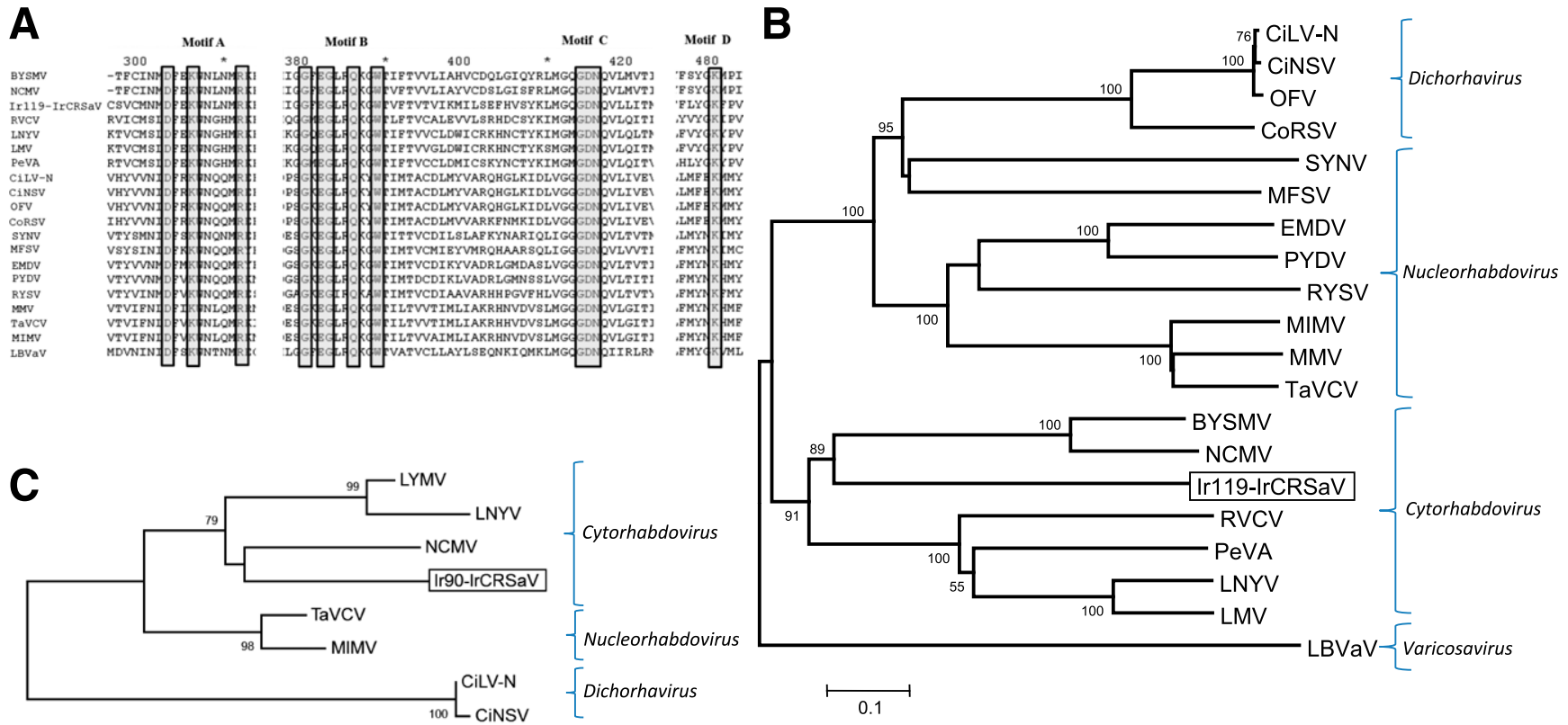

$\underset{0.2}{1}$

Fig. 4. A, Multiple alignment of the $L$ proteins showing four very distinct conserved motifs among members of the family Mononegavirales. Conserved residues are boxed. B, Phylogenetic tree generated by the neighbor-joining method from the alignment of the amino acid sequence of the viral polymerase $L$ protein of representative members of the families Rhabdoviridae and Varicosavirus. C, Phylogenetic tree constructed with the partial amino acid sequence of nucleoprotein N. Bootstrap values for 1,000 replicates at the main branches of the phylogenetic trees. Branch length is proportional to number of amino acid changes. Accession numbers of reference protein sequences are $\mathbf{A}$ and B, Barley yellow striate mosaic virus (BYSMV, ACT21686); Citrus leprosis virus nuclear type (CiLV-N, AGN91973); Citrus necrotic spot virus (CiNSV, AGQ21977); Coffee ringspot virus (CoRSV, AHH44830); Eggplant mottled dwarf virus (EMDV, AHL89007); Lettuce big-vein associated virus (LBVaV, YP_002308576); Lettuce necrotic yellows virus (LNYV, YP_425092); Lettuce yellow mottle virus (LMV, YP_002308376); Maize fine streak virus (MFSV, YP_052849); Maize Iranian mosaic virus (MIMV, YP_002308459); Maize mosaic virus (MMV, YP_052855); Northern cereal mosaic virus (NCMV, ADE61677); Orchid fleck virus (OFV, BAH97108); Persimmon virus A (PeVA YP 006576506.2); Potato yellow dwarf virus (PYDV, YP 004927971); Raspberry vein chlorosis virus (RBCV, CBL76312); Rice yellow stunt virus (RYSV, BAI79332); Sonchus yellow net virus (SYNV, NP_042286); Taro vein chlorosis virus (TaVCV, YP_224083); and C, Citrus leprosis virus nuclear type (CiLV-N, AlH07332); Citrus necrotic spot virus (CiNSV, AGQ21972); Lettuce necrotic yellows virus (LNYV, CAG34090); Lettuce yellow mottle virus (LMV, YP_002308371); Maize Iranian mosaic virus (MIMV, YP_002308454); Northern cereal mosaic virus (NCMV, NP_057954); Taro vein chlorosis virus (TaVCV, AHM10390)

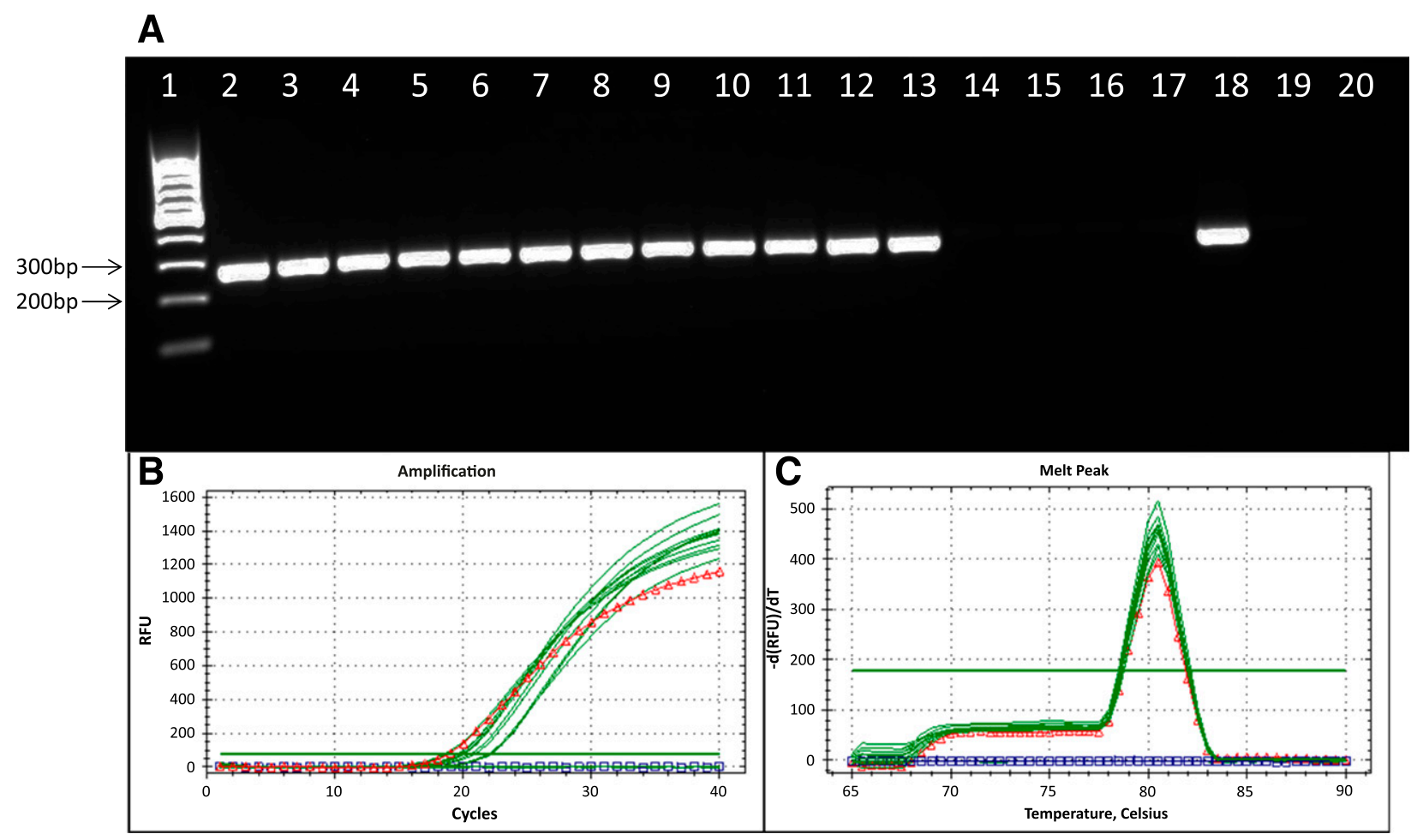

Fig. 5. Results of Iranian citrus ringspot-associated virus (IICRSaV) detection using reverse-transcription polymerase chain reaction (RT-PCR). A, Agarose gel electrophoresis of RT-PCR products of IrCRSaV amplified using the primers IrF/lrR. Lane 1: Gene ruler 100-bp DNA ladder (Thermo Scientific); lanes 2 to 10: field-grown symptomatic trees; lanes 11 to 13: graftinoculated Duncan grapefruit, Mexican lime, and sour orange; lanes 14 to 17: field-grown symptomless trees; lane 18: symptomatic Phaseolus vulgaris; lane 19: healthy sour orange; lane 20: nontemplate control. B, Amplification plot and C, derivative melting curves (dRFU/dT) generated by one-step SYBR Green I-based RT-PCR assays using the abovementioned panel of samples. Positive control reported in red, with curve segments associated with triangles; negative control reported in blue, with curve segments associated with squares. 
or sensitivity of the most commonly used citrus varieties, and (v) the production and use of virus-free propagating materials for nursery stock.

\section{Acknowledgments}

This work was supported by grants from CNR CISIA: "Valorizzazione delle risorse genetiche di colture mediterranee attraverso approcci di metagenomica, tracrittomica e analisi funzionale per la caratterizzazione di germoplasma autoctono, endofiti, agenti di biocontrollo e fitopatogeni (METARGERM)", and experiments were conducted using the equipment of "Rete di Laboratori Pubblici SELGE: Regione Puglia (cod. 14)".

\section{Literature Cited}

Amiri, F., Rahimian, H., and Izadpanah, K. 1992. Graft transmission of Iranian citrus ring spot. Iran. J. Plant Pathol. 29:226.

Bové, J. M. 1995. Virus and Virus Like Disease of Citrus in the Near East Region. FAO, Rome.

Cruz-Jaramillo, J. L., Ruiz-Medrano, R. R., Rojas-Morales, L., López-Buenfil, J. A., Morales-Galván, O., Chavarín-Palacio, C., Ramírez-Pool, J. A., and Xoconostle-Cázares, B. 2014. Characterization of a proposed Dichorhavirus associated with the citrus leprosis disease and analysis of the host response. Viruses 6:2602-2622.

Deng, D., Mcgrath, P. F., Robinson, D. J., and Harrison, B. D. 1994. Detection and differentiation of whitefly-transmitted geminiviruses in plants and vector insects by the polymerase chain reaction with degenerate primers. Ann. Appl. Biol. 125:327-336.

Dietzgen, R. G., Kuhn, J. H., Clawson, A. N., Freitas-Astúa, J., Goodin, M. M., Kitajima, E. W., Kondo, H., Wetzel, T., and Whitfield, A. E. 2014. Dichorhavirus: A proposed new genus for Brevipalpus mite-transmitted, nuclear, bacilliform, bipartite, negative-strand RNA plant viruses. Arch. Virol. 159:607-619.

Dovas, C. I., and Katis, N. I. 2003. A spot nested RT-PCR method for simultaneous detection of members of the vitivirus and foveavirus in grapevine. J. Virol. Methods 107:99-106.

Ha, C., Coombs, S., Revill, P. A., Harding, R. M., Vu, M., and Dale, J. L. 2008. Design and application of two novel degenerate primer pairs for the detection and complete genomic characterization of potyviruses. Arch. Virol. 153:25-36.

Izadpanah, K., and Rahimian, H. 1978. Virus-like diseases of citrus in Fars. Pages 173-191 in: Rep. Act. Coll. Agric. Res. Cent. No. 4. Shiraz University, Shiraz, Iran.

Jackson, A. O., and Christie, S. R. 1977. Purification and some physicochemical properties of sonchus yellow net virus. Virology 77:344-355.

Locali-Fabris, E. C., Freitas-Astúa, J., and Machado, M. A. 2012. Genus Cilevirus. Pages 1139-1142 in: Virus Taxonomy: Classification and Nomenclature of Viruses. Ninth Report of the International Committee on Taxonomy of Viruses. A. M. Q. King, M. J. Adams, E. B. Carstens, and E. J. Lefkowitz, eds. Elsevier, San Diego, CA.

Loconsole, G., Onelge, N., Potere, O., Giampetruzzi, A., Bozan, O., Satar, S., De Stradis, A., Savino, V., Yokomi, R. K., and Saponari, M. 2012a. Identification and characterization of citrus yellow vein clearing virus, a putative new member of the genus Mandarivirus. Phytopathology 102:1168-1175.

Loconsole, G., Saldarelli, P., Doddapaneni, H., Savino, V., Martelli, G. P., and Saponari, M. 2012b. Identification of a single-stranded DNA virus associated with citrus chlorotic dwarf disease, a new member in the family Geminiviridae. Virology 432:162-172.
Loconsole, G., Saponari, M., and Savino, V. 2010. Development of real-time PCR based assays for simultaneous and improved detection of citrus viruses. Eur. J. Plant Pathol. 128:251-259.

Martelli, G. P., and Russo, M. 1984. Use of thin sectioning for the visualization and identification of plant viruses. Methods Virol. 8:143-224.

Milne, R. G. 1993. Electron microscopy of in vitro preparations. Pages 215-251 in: Diagnosis of Plant Virus Diseases. R. E. F. Matthews, ed. CRC Press, Boca Raton, FL.

Milne, R. G., Garcia, M. L., and Grau, O. 2000. Genus Ophiovirus. Type species citrus psorosis virus (CPsV). Pages 627-631 in: Virus Taxonomy, 7th Rep. Int Comm. Taxonomy of Viruses. M. H. V. Van Regenmortel, C. M. Fauquet, D. H. L. Bishop, E. B. Carstens, M. K. Estes, S. M. Lemon, J. Maniloff, M. A. Mayo, D. J. McGeoch, C. R. Pringle, and R. B. Wickner, eds. Academic Press, San Diego, CA

Poch, O., Blumberg, B. M., Bougueleret, L., and Tordo, N. 1990. Sequence comparison of five polymerases ( $\mathrm{L}$ proteins) of unsegmented negativestranded RNA viruses: Theoretical assignment of functional domain. J. Gen Virol. 71:1153-1162.

Roistacher, C. N. 1993. Psorosis-A review. Pages 139-154 in: 12th IOCV Conf., Riverside, $\mathrm{CA}$

Roy, A., Fayad, A., Barthe, G., and Brlansky, R. H. 2005. A multiplex polymerase chain reaction method for reliable, sensitive and simultaneous detection of multiple viruses in citrus trees. J. Virol. Methods 129:47-55.

Roy, A., Stone, A. L., Shao, J., Otero-Colina, G., Wei, G., Choudhary, N., Achor, D., Levy, L., Nakhla, M. K., Hartung, J. S., Schneider, W., and Brlansky, R. H 2015. Identification and molecular characterization of nuclear Citrus leprosis virus, a member of the proposed Dichorhavirus genus infecting multiple citrus species in Mexico. Phytopathology 105:564-575.

Ruiz-Ruiz, S., Ambrós, S., Vives, M. del C., Navarro, L., Moreno, P., and Guerri, J. 2009. Detection and quantitation of Citrus leaf blotch virus by TaqMan realtime RT-PCR. J. Virol. Methods 160:57-62.

Rustici, G., Accotto, G. P., Noris, E., Masenga, V., Luisoni, E., and Milne, R. G. 2000. Indian citrus ringspot virus: A proposed new species with some affinities to potex-, carla-, fovea- and allexiviruses. Arch. Virol. 145:1895-1908.

Rustici, G., Milne, R. G., and Accotto, G. P. 2002. Nucleotide sequence, genome organisation and phylogenetic analysis of Indian citrus ringspot virus. Arch. Virol. 147:2215-2224.

Saponari, M., Loconsole, G., Liao, H.-H., Jiang, B., Savino, V., and Yokomi, R. K 2013. Validation of high-throughput real time polymerase chain reaction assays for simultaneous detection of invasive citrus pathogens. J. Virol. Methods 193 478-486.

Schnell, M. J., and Conzelmann, K. K. 1995. Polymerase activity of in vitro mutated rabies virus L protein. Virology 214:522-530.

Sharma, S., Singh, B., Nagpal, A., Virk, G. S., and Zaidi, A. 2009. Indexing tools for Indian citrus ring spot virus. Open Biol. J. 2:27-31

Tamura, K., Peterson, D., Peterson, N., Stecher, G., Nei, M., and Kumar, S. 2011 MEGA5: Molecular evolutionary genetics analysis using maximum likelihood, evolutionary distance, and maximum parsimony methods. Mol. Biol. Evol. 28: 2731-2739.

Timmer, L. W., Garnsey, S. M., and Graham, J. H. eds. 2000. Compendium of Citrus Diseases, 2nd ed. American Phytopathological Society, St. Paul, MN.

Vaira, A. M., Accotto, G. P., Costantini, A., and Milne, R. G. 2003. The partial sequence of RNA1 of the ophiovirus Ranunculus white mottle virus indicates its relationship to rhabdoviruses and provides candidate primers for an ophiovirus-specific RT-PCR test. Arch. Virol. 148:1037-1050.

Yassaie, M., and Izadpanah, K. 2000. Electrophoretic profiles of protein and nucleic acid; attempts for mechanical transmission of Fars isolate of Citrus ring spot virus and its comparison with certain foreign isolates. Page 135 in: 14th Iran. Plant Prot. Cong., Isfahan, Iran. 